\title{
OPERATING PERFORMANCE OF A TRACTOR WORKING WITH DIFFERENT RATIOS OF CASTOR BEAN AND JATROPHA BIODIESEL
}

Carla da Penha Simon ${ }^{1}$, Edney Leandro da Vitória ${ }^{2}$, Elcio das Graça Lacerda ${ }^{3}$ \& Ismael Lourenço de Jesus Freitas ${ }^{4}$

\author{
1 - Engenheira Agrônoma, Mestranda na UFES - Campus São Mateus, carlasimon.simon@gmail.com \\ 2- D.Sc. em Engenharia Agrícola, Professor Titular da UFES - Campus São Mateus, vitoria.edney@gmail.com \\ 3 - D.Sc. em Engenharia Agrícola, Professor Titular do IFES - Campus Santa Teresa. elciogdl@hotmail.com \\ 4 - D.Sc. em Produção Vegetal, Pós-doutorando da UFES - Campus São Mateus, ismaelljf@yahoo.com.br
}

\section{Keywords:}

bioenergy

biofuels

specific consumption

smoke opacity

\section{ABSTRACT}

There is a growing global quest for clean energy. One of the alternatives is the use of agroenergy, which is the use of vegetable and animal raw material for the production of biofuels. Among them, biodiesel stands out for its renewable and biodegradable nature. The objective of this study was to evaluate the operating performance and smoke opacity of an agricultural tractor fed with different types and ratios of castor bean and Jatropha biodiesels. The study was conducted at Fazenda Experimental CEUNES / UFES, Campus São Mateus - ES. The mixture ratios of biodiesel/diesel used were: B0 (0/100\%), B5 (5\% 95\%), B15 (15\%/85\% diesel), B25 (25\%/75\%), B50 (50\%/50\%), B75 (75\%/25\%), and B100 (100\%/0\%). The results showed an increase of $20.0 \%$ and $14.8 \%$ in the specific consumption comparing B0 to B100 of castor and Jatropha, respectively. The smoke opacity reduced $24.50 \%$ and $54.05 \%$ when working with castor and Jatropha biodiesel, respectively. The smoke opacity of the castor B100 is $65.68 \%$ higher when compared to Jatropha B100.

\section{Palavras-chave:}

agroenergia

biocombustível

consumo específico

opacidade da fumaça

\section{DESEMPENHO OPERACIONAL DE UM TRATOR FUNCIONANDO COM DIFERENTES PROPORÇÕES DE BIODIESEL DE MAMONA E PINHÃO-MANSO}

\section{RESUMO}

É crescente a busca mundial por energias limpas. Uma das alternativas é o uso da agroenergia que consiste no uso de matérias-primas vegetais e animais para produção de biocombustíveis, dentre eles destaca-se o biodiesel devido ao seu caráter renovável e biodegradável. Objetivou-se com o presente trabalho avaliar o desempenho operacional e a opacidade da fumaça do trator agrícola alimentado com diferentes tipos e proporções de biodiesel de mamona e biodiesel de pinhão-manso. O estudo foi conduzido na Fazenda Experimental CEUNES/UFES, Campus São Mateus-ES. As proporções de mistura biodiesel/diesel utilizadas foram: B0 (0 / 100\%), B5 (5\% / 95\%); B15 (15\% / 85\% de diesel); B25 (25\% / 75\%); B50 (50\% / 50\%); B75 (75\% / 25\%) e B100 (100\% / 0\%). Os resultados evidenciaram aumento de $20,0 \%$ e $14,8 \%$ no consumo específico, comparando B0 a B100 de mamona e pinhão-manso, respectivamente. A opacidade da fumaça reduziu $24,50 \%$ e $54,05 \%$ quando se trabalhou com biodiesel de mamona e pinhãomanso, respectivamente. A opacidade da fumaça do B100 de mamona é 65,68\% maior quando comparada à B100 de pinhão-manso. 


\section{INTRODUCTION}

Global energy base is strongly linked to fossil fuels, especially with oil. However, these resources are finite and both their extraction and use cause harmful damage to the environment. There is a growing global concern for environmental responsibility; during the UN Climate Conference (COP21), it was established that climate change is a common concern of humankind, encompassing all countries and all kinds of emissions. It was also pointed out that deep cuts in global emissions of greenhouse gases will be necessary (UNITED NATIONS, 2015). Thus, various technologies have been developed; one of the alternatives is the use of agro-energy arising from organic sources of non-fossil origin (wood, natural gas, ethanol, and biodiesel) that is produced biomass and in photosynthesis is transformed into fuel energy. Biofuels appear as a promising source to meet the needs of the consumer market as well as a regulatory framework in the supply security.

Biodiesel is a biofuel that can be synthesized from animals and transesterified vegetable oils; tens of vegetable species in Brazil are used in the production of fuel, including soy, palm, sunflower, babaçu, peanut, castor bean, and Jatropha. According to ALVIM et al., (2015), biodiesel is a renewable, biodegradable fuel, resulting from the blend of vegetable oil or animal fat and anhydrous alcohol in the presence of a catalyst.

This biofuel is already considered a possible solution to the uncertainties and doubts of the energy future. Because of its high compatibility with diesel, since it has properties as similar chemical structure and energy content, it can be mixed in almost any ratio without the need for modifications in the diesel engines (GIAKOUMIS, 2013).

The agricultural sector accounts for a large part of pollutant emissions into the atmosphere, because the entire system virtually depends on petroleumbased fuels. The Ministry of Mines and Energy said that the agricultural sector in 2014 consumed more than 6.1 million tons of diesel, representing $55.2 \%$ of total consumption of energy resources, standing out as the main energy source of the current agricultural scenario (BRAZIL, 2015).

According to SIQUEIRA et al. (2013), the use of vegetable oil in natura may present advantages over biodiesel, possibly with full independence from petroleum-based products; it does not require longterm investments, in particular, with equipment; and provides immediate return of the capital invested and encourages the production of oilseeds.

LIMA et al. (2015), evaluating smoke opacity in agricultural tractors with three kinds of oleaginous seeds, when counteracted the B0 (diesel) with B100, the smoke opacity reduced $53.9,53.5$, and $26.1 \%$ with tucumã, murumuru, and soybean, respectively. The authors also concluded that the different diesel/ biodiesel ratios did not compromise the operation of the tractor.

Resolution number 14 of the National Petroleum Agency, published on May 11th, 2012, that altered the Law 11,094/05, the Biodiesel Law, established that from January 1st, 2010, the biodiesel content to be added to diesel oil should be of $5 \%$ in volume. The expected demand to meet this percentage is approximately 900 million L per year, which equates to approximately 1.5 million hectares cultivated with oleaginous species, about $1 \%$ of the Brazilian production area (FIORESE et al., 2012).

There are many biodiesel advantages, but studies should be developed in order to assess its feasibility. Performance tests are important to generate knowledge of the machinery operation characteristics with the new fuels. Therefore, this study aimed to evaluate smoke opacity and performance of agricultural tractors according to the type of biodiesel (castor and Jatropha) and mixing ratios with diesel.

\section{MATERIAL AND METHODS}

The experiment was conducted in the experimental area of agricultural production at Fazenda Experimental from Federal University of Espírito Santo, Campus São Mateus/ES, located in the coordinates $18^{\circ} 42^{\prime} \mathrm{S}$ and $39^{\circ} 51^{\prime}$ at $36.0 \mathrm{~m}$ altitude, in December 2014. The average annual temperature in the region is $24^{\circ} \mathrm{C}$, with the average annual rainfall of $1100 \mathrm{~mm}$. According to the Koppen's climate classification, the climate of São Mateus is Aw type, specifically: humid tropical, with dry winter, and maximum rainfall in summer.

The soil of the experimental area was classified as typical Oxisol with smooth undulated relief and mean slope of $1 \%$, according to the Brazilian System of Soil Classification (EMBRAPA, 2013). The average water content in the soil on the day of the assay, in the profile from 0.00 to 0.20 and from 0.20 to $0.40 \mathrm{~m}$ depth, was $12.5 \%$ and $13.5 \%$, respectively, according to the standard gravimetric method. The particle size analysis of 0.00 to 0.20 
$\mathrm{m}$ layer for clay, silt, thin sand, and coarse sand was $0.400 \mathrm{~kg} \mathrm{~kg}^{-1} ; 0.150 \mathrm{~kg} \mathrm{~kg}^{-1} ; 0.150 \mathrm{~kg} \mathrm{~kg}^{-1}$, and 0.200 $\mathrm{kg} \mathrm{kg}^{-1}$, respectively; therefore, being classified with sandy-clayey texture (FERREIRA, 2010).

We used Jatropha and castor biodiesels and commercial diesel classified according to the resolution of the ANP number 42, December 16th, 2009 (ANP, 2009), with total sulfur maximum amount of $1,800 \mathrm{mg} \mathrm{kg}^{-1}$ and specific mass, acquired in São Mateus - ES.

The tractor used in the tests was an Ursus, model $4-85 \mathrm{M}, 4 \times 2$ with front-wheel drive, maximum engine power of $62.5 \mathrm{~kW}(85 \mathrm{hp})$ at $2200 \mathrm{rpm}$. It is equipped with turbocharger and intercooler, total mass of 3,300 kg distributed at 40 and $60 \%$ in the front and rear axles, respectively; mass/power ratio of $52.8 \mathrm{~kg} \mathrm{~kW}^{-1}\left(38.8 \mathrm{~kg} \mathrm{hp}^{-1}\right)$; equipped with 11.2 24 tires on the front axle and 16.9-30 on the rear axle, calibrated according to the manufacturer's recommendation.

The braking tractor used was an Agrale, model 5075.4; 4×2; front-wheel drive; $55.2 \mathrm{~kW}(75 \mathrm{hp})$ engine power at $2300 \mathrm{rpm}$; total mass of $3,000 \mathrm{~kg}$, distributed at 40 and $60 \%$, respectively, in the front and rear axles; equipped with 12.4-24 tires on the front axle and 16.9-30 on the rear axle.

Between the assays, all the unconsumed fuel was drained from the tanks, filters, and pipes, in order to avoid contamination of the following assay. Furthermore, after fuel changing, the engine remained in operation for fifteen minutes before the start of each test.

The test tractor was equipped with Kratos load cell, model IK-15, with capacity of $50 \mathrm{kN}$; conditioning and data acquisition device Quantum $\mathrm{X}$; and fuel consumption meter Flowmates, model Oval MIII.

The tractor performance with the use of different diesel and biodiesel ratios was analyzed by measurement of specific, ponderal, and volumetric consumption. We conducted a preliminary test in order to set the load corresponding to the maximum effort, technically feasible, with which the test tractor could pull. The load was achieved by combining the braking tractor gears.

The braking tractor was coupled to the test tractor through a steel chain, forming a train. It worked off and geared in order to provide load on the test tractor drawbar as uniformly as possible, having the working speed and the required load obtained by combining the gearshift in $3^{\text {rd }}$ gear reduced.
The test tractor started moving $20 \mathrm{~m}$ before the point that indicated the beginning of the evaluation. When the reference point of the tractor, which is the center of the rear wheel, coincided with the start point of the evaluations, the data acquisition system was triggered. The procedure was stopped when the 50-m long portion was run, moment in which the reference point coincided with the end of the evaluation.

The volumetric fuel consumption was measured, in each plot, from the difference between the total volume of feeding fuel in the entrance of the injection pump and the total volume of fuel that returned to the reservoir. This data and the fuel density determined the volumetric hourly consumption (VHC), the ponderal hourly consumption (PHC), and the specific consumption (SC).

Based on the consumed volume and the driving time in each plot, the Cvh was determined, according to Equation 1:

$\mathrm{VHC}=\left(\frac{\mathrm{Vf}-\mathrm{Vr}}{\mathrm{t}}\right) \times 3.6$

in which,

VHC is the volumetric hourly consumption $\left(\mathrm{L} \mathrm{h}^{-1}\right)$; $\mathrm{Vf}$ is the feeding fuel volume $(\mathrm{mL})$;

$\mathrm{Vr}$ is the return fuel volume $(\mathrm{mL})$;

$\mathrm{T}$ - course time in the plot (s), and

3.6 is the conversion factor.

It is possible to calculate $\mathrm{VHC}$, the density influence of the feeding fuel and the return during the test, according to Equation 2:

$$
\mathrm{PHC}=\frac{\left(\mathrm{Vf} \times \mathrm{d}_{1}-\mathrm{Vr} \times \mathrm{d}_{2}\right)}{\mathrm{t}} \times 0.0036
$$

in which,

PHC - ponderal hourly consumption $\left(\mathrm{kg} \mathrm{h}^{-1}\right)$;

$\mathrm{Vf}$ is the feeding fuel volume (ml);

$\mathrm{d}_{1}$ is feeding fuel density $\left(\mathrm{kg} \mathrm{m}^{-3}\right)$;

$\mathrm{Vr}$ is the return fuel volume $(\mathrm{mL})$;

$\mathrm{d}_{2}$ - return fuel density $\left(\mathrm{kg} \mathrm{m}^{-3}\right)$;

$\mathrm{t}$ is the course time in the plot (s), and

0.0036 is the conversion factor.

The specific consumption is the fuel consumption expressed in mass units per power unit required in the drawbar, according to Equation 3: 


$$
\mathrm{SC}=\left(\frac{\mathrm{PHC}}{\mathrm{P}_{\mathrm{DB}}}\right) * 1000
$$

in which,

$\mathrm{SC}$ is the specific fuel consumption $\left(\mathrm{g} \mathrm{kW}^{-1} \mathrm{~h}^{-1}\right)$; PHC is the ponderal hourly consumption $\left(\mathrm{kg} \mathrm{h}^{-1}\right)$; $\mathrm{P}_{\mathrm{DB}}$ is the power on drawbar $(\mathrm{kW})$, and 1000 is the conversion factor.

A second assay was done according to the method of free acceleration, in which the engine is subjected to the rotation speed, which is obtained with the throttle in its maximum level. Its developed power is only absorbed by the inertia of the engine mechanical components (clutch - primary shaft of the gearbox), once the vehicle is parked. The smoke opacity measurements are made in $\mathrm{K}$, which is the coefficient of light absorption and has the unit $\mathrm{m}^{-1}$, according to the manufacturer's manual (TECNOMOTOR, 2012).

Both tests were performed with a completely randomized design and, the data analyzed in a factorial $6 \times 2$, with four replications, totaling 48 observations. Combinations of factors were six ratios of biodiesel/diesel mixture (B0, B5, $\mathrm{B} 25, \mathrm{~B} 50, \mathrm{~B} 75$, and $\mathrm{B} 100$, in which the letter indicates the presence of biodiesel and the number represents the biodiesel percentage in diesel). In the performance test, each experimental plot had $50.0 \mathrm{~m}$ in length and, between each other in the longitudinal direction, there was a $20-\mathrm{m}$ space for maneuvers, machinery traffic, and stabilization of the motomechanized set in each treatment.

Data were tabulated and subjected to analysis of variance (ANOVA). When significant differences were observed in ANOVA, the comparison test of Tukey was applied at 0.05 significance. For specific fuel consumption and smoke opacity, ANOVA was used to select the most significant equation model exponent and that was more appropriate to explain the behavior of these variables due to the biodiesel ratio.

\section{RESULTS AND DISCUSSION}

The tested tractor had lower consumption of Jatropha biodiesel compared to castor biodiesel. The significant difference was $10.7 \%$ and $12.6 \%$ for VHC and PHC, respectively (Table 1).

Table 1. Analysis of variance and mean test for the variables volumetric hourly consumption, ponderal hourly consumption, and specific consumption according to biodiesel ratios.

\begin{tabular}{cccc}
\hline Factor & $\begin{array}{c}\text { Volumetric hourly consumption } \\
\left(\mathrm{L} \mathrm{h}^{-1}\right)\end{array}$ & $\begin{array}{c}\text { Ponderal hourly consumption } \\
\left(\mathrm{kg} \mathrm{h}^{-1}\right)\end{array}$ & $\begin{array}{c}\text { Specific consumption } \\
\left(\mathrm{g} \mathrm{kW} \mathrm{h}^{-1}\right)\end{array}$ \\
\hline $\begin{array}{c}\text { Biodiesel (B) } \\
\text { Castor }\end{array}$ & $12.2 \mathrm{a}$ & $10.3 \mathrm{a}$ & $261 \mathrm{a}$ \\
Jatropha & $10.9 \mathrm{~b}$ & $9.0 \mathrm{~b}$ & $240 \mathrm{~b}$ \\
\hline Biodiesel ratio (BR) & & & \\
BO & $11.5 \mathrm{a}$ & $9.7 \mathrm{ab}$ & 242 \\
B5 & $11.2 \mathrm{a}$ & $9.1 \mathrm{a}$ & 216 \\
B25 & $11.2 \mathrm{a}$ & $9.5 \mathrm{ab}$ & 231 \\
850 & $11.4 \mathrm{a}$ & $9.3 \mathrm{ab}$ & 233 \\
B75 & $11.7 \mathrm{a}$ & $9.2 \mathrm{~b}$ & 224 \\
8100 & $11.6 \mathrm{a}$ & $9.1 \mathrm{~b}$ & 215 \\
\hline F test & & $43.3651^{* *}$ & $37.9191^{* *}$ \\
B & $50.4407^{* *}$ & $3.7666^{* *}$ & $17.2124^{* *}$ \\
BR & $1.9877 \mathrm{NS}$ & $1.1245 \mathrm{NS}$ & $3.0179^{*}$ \\
BxBR & $1.0012 \mathrm{NS}$ & 4.74 & 3.8 \\
\hline CV(\%) & 5 & $\mathrm{n}$ & \\
\hline
\end{tabular}

*Significant $(\mathrm{P}<0.01)$. **Significant $(\mathrm{P}<0.05)$. NS - not significant; CV- coefficient of variation.

Means followed by the sarne lowercase letter in the column do not differ by Tukey's test 0.05 probability. 
OPERATING PERFORMANCE OF A TRACTOR WORKING WITH DIFFERENT RATIOS OF CASTOR BEAN...

We observed that the specific consumption of the tractor was $18.2 \%$ lower when it worked with $100 \%$ Jatropha biodiesel, compared to $100 \%$ castor biodiesel (Table 2). The changes in fuel consumption, in three observations, may be attributed to the difference in the cetane number among the different sources of biodiesel.

The results of the VHC and PHC (Table 1) show that there was no significant difference for these variables when comparing B0 to B100. The results indicate that the $\mathrm{VHC}$ increase was due to the lower calorific value of biodiesel compared to diesel. Thus, it was necessary to release greater amount of fuel to accomplish the same amount of work. The results contradict the data obtained by SILVA et al. (2012) and IAMAGUTI et al. (2016), who worked with tractors of the same power range and, comparing the $\mathrm{B} 0$ and $\mathrm{B} 100$ ratios, observed VHC increase of $10.7 \%$ and $31.6 \%$, respectively.

The specific consumption data (Table 2) indicates that, for mixing ratio, when comparing B0 and B100, the consumption increased by 20.0 and $12.9 \%$ for castor and Jatropha biodiesel, respectively. Such differences are due to the different densities between diesel and biodiesel, biodiesel having higher density, and also to the lower calorific value of biodiesel compared to diesel according to MURUGESAN et al. (2009).

VITÓRIA et al. (2012) and CUNHA et al. (2012) obtained results that indicated higher specific consumption when the engine was fed $100 \%$ biodiesel compared to commercial diesel. TABILE et al. (2009), working with medium-power tractors fueled with diesel of different concentrations of sulfur and distilled ethyl castor biodiesel, reported an increase of $38.3 \%$ in specific consumption.

The average fuel consumption in function of the type of biodiesel and the mixing ratio were adjusted, resulting in linear models for the castor and Jatropha biodiesels (Figure 1).

Table 2. Unfolding of the interaction type and biodiesel ratio for the variable specific consumption ( $\mathrm{g} \mathrm{kW}^{-1}$ $\left.\mathrm{h}^{-1}\right)$.

\begin{tabular}{ccccccc}
\hline \multirow{2}{*}{ Biodiesel type } & \multicolumn{7}{c}{ Biodiesel ratio } \\
\cline { 2 - 7 } & B0 & B5 & B25 & B50 & B75 & B100 \\
\hline Castor & $220 \mathrm{Aa}$ & $233 \mathrm{Aab}$ & $250 \mathrm{Abc}$ & $254 \mathrm{Acd}$ & $260 \mathrm{Acd}$ & $275 \mathrm{Ad}$ \\
Jatropha & $222 \mathrm{Aab}$ & $225 \mathrm{Aa}$ & $224 \mathrm{Ba}$ & $231 \mathrm{Bab}$ & $245 \mathrm{Bbc}$ & $255 \mathrm{Bc}$ \\
\hline
\end{tabular}

Means followed by the same upp ercase letter in the colwnn and lowercase letter in the row do not differ by Tukey's test 0.05 probability.

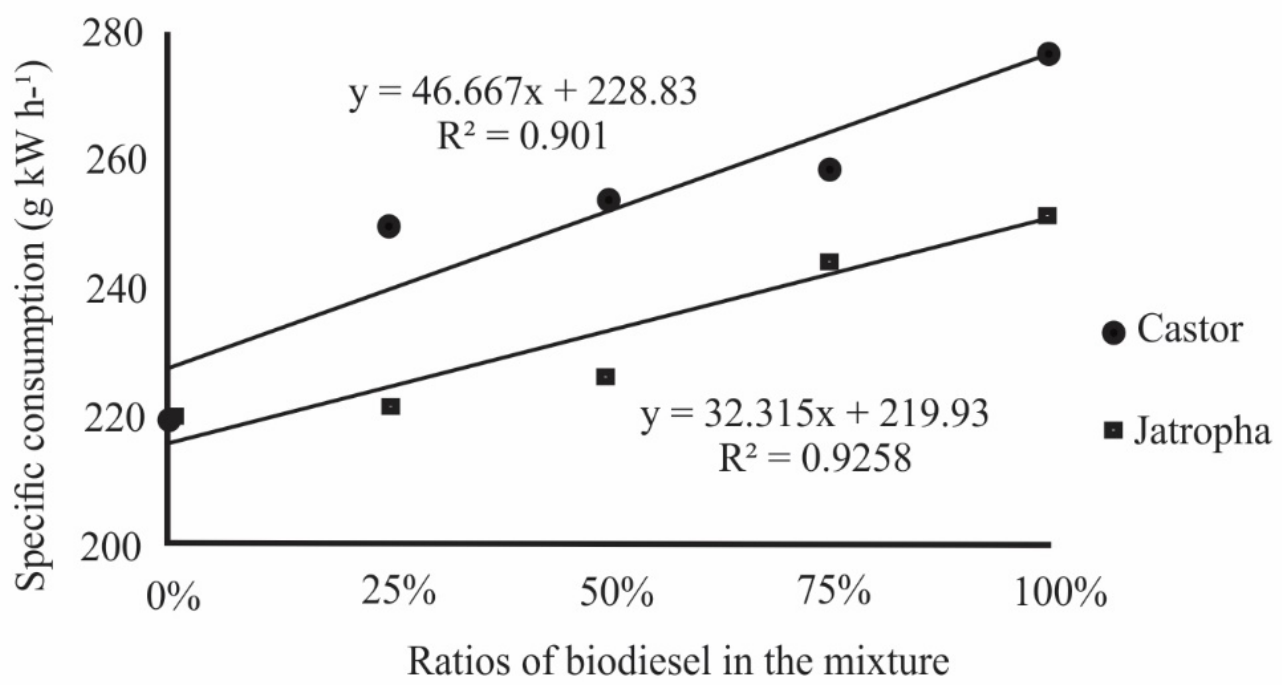

Figure 1. Specific consumption due to the type and biodiesel ratios in the mixture. 
The results of smoke opacity are presented in Table 3. Due to the interaction, the data were unfolded and presented in Table 4.

Table 3. Analysis of variance and mean test for the variable smoke opacity $\left(\mathrm{m}^{-1}\right)$

\begin{tabular}{cc}
\hline Factor & Opacity $\left(\mathrm{m}^{-1}\right)$ \\
\hline \multicolumn{2}{c}{ Biodiesel (B) } \\
Castor & 1.98 \\
Jatropha & 1.92 \\
\hline Biodiesel ratio (BR) \\
BO & 2.28 \\
B5 & 2.2 \\
B25 & 2.13 \\
B50 & 1.95 \\
B75 & 1.71 \\
B100 & 1.43 \\
\hline B & $1743.2302 * *$ \\
BR & $947.5276 * *$ \\
B x BR & $84.1117 * *$ \\
\hline CV(\%) & 3.15 \\
\hline
\end{tabular}

Means followed by the sarne lowercase letter in the colurnn do not differ by Tukey's test 0.05 probability. *Significant $(\mathrm{P}<0.01)$. **Significant $(\mathrm{P}<0.05)$. CV-coefficient of variation.
Castor biodiesel decreased in particulate emissions when $50 \%$ of castor biodiesel was added to diesel (Table 4). Comparing B0 B100, the decrease in opacity was $24.5 \%$. The Jatropha biodiesel provided a reduction in emissions when $5 \%$ biodiesel was added to diesel and a reduction of $54.05 \%$ in smoke opacity. The Jatropha biodiesel provided lower emission material when compared to castor biodiesel.

Biodiesel derived from castor and Jatropha provided significant reduction in smoke opacity. This is due to the better combustion when using biodiesel, once there is free oxygen in the molecule, increasing efficiency in combustion. Similar results were found in CARVALHO (2013) and SILVA (2012).

The results obtained for smoke opacity, if compared with the norm of CONAMA number 251, 1999 (CONAMA, 2014), indicates that the tractor would be approved if the emission test was applied, because the values are lower than $2.5 \mathrm{~m}^{-1}$, which confirms biodiesel as a diminutive of environmental pollution (COSTA NETO et al., 2000).

After being analyzed, the smoke opacity data were adjusted, resulting in linear models for Jatropha and castor biodiesel (Figure 2).

Table 4. Unfolding of the interaction type and biodiesel ratio for the variable smoke opacity $\left(\mathrm{m}^{-1}\right)$

\begin{tabular}{crrrrrr}
\hline \multirow{2}{*}{ Biodiesel type } & \multicolumn{7}{c}{ Biodiesel ratio } \\
\cline { 2 - 7 } & $\mathrm{B} 0$ & $\mathrm{~B} 5$ & $\mathrm{~B} 25$ & $\mathrm{~B} 50$ & $\mathrm{~B} 75$ & $\mathrm{~B} 100$ \\
\hline Castor & $2.24 \mathrm{Aa}$ & $2.35 \mathrm{Aa}$ & $2.31 \mathrm{Aab}$ & $2.17 \mathrm{Ac}$ & $1.93 \mathrm{Ad}$ & $1.69 \mathrm{Ae}$ \\
Jatropha & $2.22 \mathrm{Aa}$ & $2.00 \mathrm{Bb}$ & $1.90 \mathrm{Bb}$ & $1.73 \mathrm{Bd}$ & $1.43 \mathrm{Be}$ & $1.02 \mathrm{Bf}$ \\
\hline
\end{tabular}

Means followed by the same uppercase letter in the column and lowercase letter in the row do not differ by Tukey's test 0.05 probability.

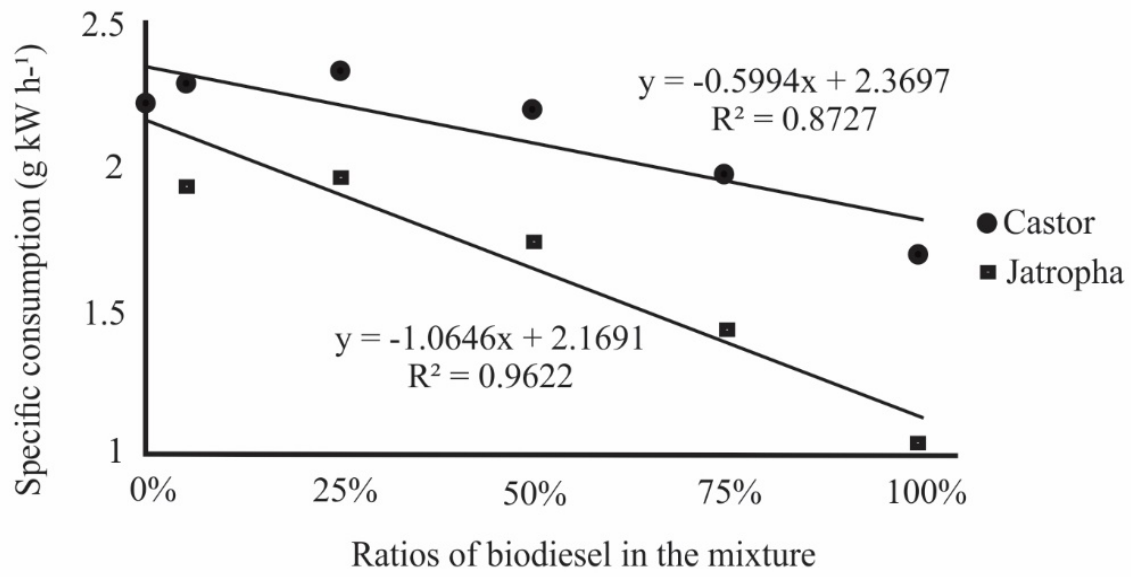

Figure 2: Smoke opacity in function of the type and mixing biodiesel ratios with diesel. 
OPERATING PERFORMANCE OF A TRACTOR WORKING WITH DIFFERENT RATIOS OF CASTOR BEAN...

DELALIBERA et al. (2012) reported an increase in emissions of particulate matter when the mixture of vegetable oil and diesel was used. PRABHAKAR \& ANNAMALAI (2011), evaluating five types of biodiesel in different ratios, observed higher opacity values in the biodiesel than in the diesel, due to the higher viscosity that leads to incomplete combustion.

\section{CONCLUSIONS}

- Fuel consumption with Jatropha biodiesel is lower when compared to the castor biodiesel;

- The Jatropha biodiesel has smoke opacity within the emission parameters established by current law in Brazil;

- The opacity of B100 castor is $65.68 \%$ higher than B100 Jatropha.

\section{REFERENCES}

ALVIM, J.C.; ALVIM, F.A.L.S.; SALES, V.H.G.; SALES, P.V.G.; OLIVEIRA, E.M.; COSTA, A.C.R. Biorrefinarias: Conceitos, classificação, matérias primas e produtos. Journal of Bioenergy and Food Science, Macapá, v.1, n.3, p.61-77, 2015.

Brasil (2015) Balanço Energético Nacional 2015, ano base 2014: Consumo de Energia por Setor. Disponível em: <http://www.mme.gov.br/ documents/10584/1143895/2.1+-+BEN+2015++ Documento + Completo + em + Portugu $\% \mathrm{C} 3 \% \mathrm{~A}$ As+-+Ingl\%C3\%AAs+(PDF)/22602d8c-a3664d16-a15f-f29933e816ff?version=1.0> Acesso em: 23 de junho de 2016.

CARVALHO FILHO, C.A.; CORTEZ, J.W.; SANTOS, V.M.L; ARCOVERDE, S.N.S. Desempenho do trator agrícola em função das marchas e das proporções de biodiesel. Energia na agricultura, Botucatu, v.28, n.3, p.135-142, 2013.

CONAMA - Conselho Nacional do Meio Ambiente. Resolução CONAMA n ${ }^{\circ} 251$, de 7 de janeiro de 1999. DOU, 12/01/1999, Seção 1, página 97.

COSTA NETO, P.R.; ROSSI, L.F.S; ZAGONEL,
G.F.; RAMOS, L.P. Produção de biocombustível alternativo ao óleo diesel através da transesterificação de óleo de soja usado em frituras. Química nova, São Paulo, v.23, n.4, p.531-537, 2000 .

CUNHA, J.P.B.; REIS, E.F.D.; COUTO, R.F.; HOLTZ, V.; LEONÍDIO, D.M. Efeito de diferentes concentrações de biodiesel no desempenho de um trator em operação de preparo do solo. Revista Agrotecnologia, Anápolis, v.2, n.2, p.53-67, 2012.

DELALIBERA, H.C.; CAMPOLINA, N.; WEIRICHNETO, P.H.; RALISCH, R. Performance of a diesel engine fueled with a preheated blend of soybean oil and petro diesel. Revista Engenharia Agrícola, Jaboticabal, v.32, n.6, p.1058-1067, 2012.

EMBRAPA Sistema brasileiro de classificação de solos. Rio de Janeiro, Centro Nacional de Pesquisa de Solos. $3^{\text {a }}$ ed. 353 p.

FERREIRA, M.M. Caracterização física do solo. In: Lier QJV (Ed.). Física do solo. Viçosa, Sociedade Brasileira de Ciências do Solo, 2010, p.2-27.

FIORESE DA, DALLMEYER AU, ROMANO LN, SCHLOSSER JF \& MACHADO PRM Desempenho de um motor de trator agrícola em bancada dinamométrica com biodiesel de óleo de frango e misturas binárias com óleo diesel. Ciência Rural, Santa Maria, v.42, n.4, p.660-666, 2012.

GIAKOUMIS, E.G. A statistical investigation of biodiesel physical and chemistry properties, and their correlation with the degree of unsaturation. Renewable Energy, Oxford, v.50, p.858-878, 2013.

LAM, M.K.; TAN, K.T.; LEE, K.T.; MOHAMED, A.R. Malaysian palm oil: surviving the food versus fuel dispute for a sustainable future. Renewable and Sustainable Energy Reviews, Colorado, v.13, n.6, p.1456-1464, 2009.

MURUGESAN, A.; UMARANI, C.; 
SUBRAMANIAN, R.; NEDUNCHEZHIAN, N. Biodiesel as an alternative fuel for diesel engines.

Renewable and Sustainable Energy Reviews, Colorado, v.13, n.3, p.653-662, 2009.

IAMAGUTI, P.S.; LOPES, A.; OLIVEIRA, M.C.J; NEVES, M.C.T.; LIRA, T.A.M.; MORETI, T.C.F.; LIMA, L.P.; KOIKE, G.H.A. Operational performance of tractor running with diesel and biodiesel from buriti oil (Mauritia flexuosa). Australian Journal of Crop Science, v.10, p.336341, 2016.

PRABHAKAR, S.; ANNAMALAI, K. Comparison of sound, exhaust gas temperature and smoke opacity characteristics of methyl esters of vegetable oils blends. Journal of Engineering and Applied Sciences, Nottingham, v.6, n.10 p.3440, 2010.

SORANSO, A.M.; GABRIEL FILHO, A.; LOPES, A.; SOUZA, E.G.; DABDOUB, M.J.; FURLANI, C.E.A.; CAMARA, F.T. Desempenho dinâmico de um trator agrícola utilizando biodiesel destilado de óleo residual. Revista Brasileira de Engenharia Agrícola e Ambiental, São Paulo, v.12, n.5, p.553559, 2008.

SILVA, M.J.; SOUZA, S.N.; SOUZA, A.A.; MARTINS, G.I.; SECCO, D. Motor gerador ciclo diesel sob cinco proporções de biodiesel com óleo diesel. Revista Brasileira de Engenharia
Agrícola e Ambiental, São Paulo, v.16, n.3, p.320326, 2012.

SIQUEIRA, W.C.; FERNANDES, H.C.; TEIXEIRA, M.M.; SANTOS, N.T.; ABRAHÃO, S.A. Desempenho na barra de tração de um trator agrícola de pneus, alimentado com misturas de óleo diesel e óleo de soja reutilizado. Revista Ceres, Viçosa, v.60, n.6, p.793-801, 2013.

TABILE, R.A.; LOPES, A.; DABDOUB, M.J.; CÂMARA, F.T.D.; FURLANI, C.E.; SILVA, R.P.D. Biodiesel de mamona no diesel interior e metropolitano em trator agrícola. Engenharia Agrícola, Viçosa, v.29, p.412-423, 2009.

TECNOMOTOR. Opacer TM 133 - Opacímetro de amostragem: Manual de Operação. São Carlos, 2012, 26p.

United Nations (2015) Framework Convention on Climate Change: Conference of the Parties. Adoption of the Paris agreement. Paris, 30 November to 11 December 2015.

VITÓRIA, E.L; OLIVEIRA, P.S; FERNANDES, H.C; LONGUI, F.C; LEITE, D.M. Desempenho comparativo de um motor ciclo Diesel alimentado com misturas de óleo Diesel e biodiesel de pinhão manso. Enciclopédia biosfera, Goiânia, v.8, n.14, p.1865, 2012. 